\title{
Influence of Sport on Student Learning Achievement with Problem Learning Methods
}

\author{
Aminuddin Prahatama Putra', Muhammad Zaini' ${ }^{1}$, M. Arsyad ${ }^{1}$, Finna Rahmiati' ${ }^{2}$, Fauziah ${ }^{3}$, Huldani ${ }^{4}$ \\ ${ }^{1}$ Biology Education Department, Faculty of Teacher Training and Education, Lambung \\ Mangkurat University, Banjarmasin, Indonesia \\ ${ }^{2}$ Biology Teacher, High School 1 Banjarbaru, Banjarbaru, Indonesia \\ ${ }^{3}$ Clinical Clerkship, Faculty of Medicine, Lambung Mangkurat University, Banjarmasin, \\ South Kalimantan, Indonesa \\ ${ }^{4}$ Department of Physiology, Faculty of Medicine, Lambung Mangkurat University, \\ Banjarmasin, South Kalimantan, Indonesia \\ Corresponding author : aminuddinpatra@ulm.ac,id
}

\section{ABSTRACT}

Cardiovascular endurance has described the functions of the respiratory, cardiovascular, and musculoskeletal systems in carrying out physical activities. This is determined by measuring VO2 max. Physical activity will increase VO2 max value. Repetitive and systematic movements stimulate organ function to work optimally, characterized by increased the denser capillary filling to meet the needs of oxygen and nutrients for cells, including brain cells, makes cognitive abilities will be better. This research was conducted on 60 elementary school students. Subjects followed multistage fitness to determine their VO2 max and physical fitness levels. Then the subject participated in teaching and learning activities with the learning method. The results showed that physical fitness and achievement were directly proportional to the increase in fitness based on problems (PBM). The increase in physical fitness level will improve academic achievement.

Keywords: sports, VO2 max, achievement, problem-based learning

\section{INTRODUCTION}

Cardiovascular endurance is an important component of physical fitness which describes the functions of the respiratory, cardiovascular, and musculoskeletal systems in carrying out physical and work activities. Cardiovascular endurance is known by measuring the maximum oxygen consumption or VO2 max. ${ }^{1}$ Physical activity types determine the value of cardiovascular endurance. Cardiovascular endurance is physiologically influenced by heredity (genetic), age, gender, and physical activity. ${ }^{2}$

VO2 max is closely related to the oxygen transport system that the body needs to produce energy. ${ }^{3}$ To reach cells in the body, the cardiovascular system pumps blood (by the heart works) and through blood vessels which eventually carry oxygen to the cells. $^{4}$

Someone who has high activity physiologically will have a good VO2 max level compared to people who have low activity. ${ }^{5}$ Good physical activity will increase the work efficiency of the heart. The work efficiency of the heart will increase according to the changes that occur. These can include changes in heart rate, stroke volume, cardiac output, including blood pressure. ${ }^{6}$

Children of school-age tend to be active and have a lot of activity outside. ${ }^{7}$ According to research by Hodges et al., strenuous physical activity requires 20 times the normal amount of oxygen, causing a trigger for the respiratory system and cardiovascular 
endurance to maintain the balance between oxygen pressure (PO2) value and arterial carbon dioxide pressure (PCO2) to remain normal. ${ }^{8}$

Sport is an activity that requires physical activity with adjustable intensity. Exercise causes changes in various regulatory systems of the body, such as the respiratory system and the musculoskeletal system. These changes depend on the duration, intensity, and type of the exercise. ${ }^{9}$ In a vascular system, there will be an increase in the elasticity of blood vessels accompanied by densely filled capillaries so that blood flow to organs, including the brain, and the peripheral areas of the body becomes smoother. The blood flow is rich in oxygen and nourishment so that the supply of nutrients to the organs is better. Besides, the lung will expand more and the alveoli are more active to accommodate more oxygen, this increases the flow of oxygen circulating throughout the body. ${ }^{10}$ Besides, exercise also affects the immune system with the release of the proinflammatory cytokine IL-6, secretion of growth hormone, and stimulation of Th2 which improves body health. ${ }^{11,12}$ It also improves thinking, concentration, memory, and intellectual power as a result of the release of brain-derived neurotrophic factor (BDNF) of the brain. ${ }^{13,14}$ Operational exercise of increasingly greater connections between synapses, accompanied by regions that strengthen the basal ganglia, cerebellum, and corpus callosum which increase one's ability to solve problems. ${ }^{15}$

Physical fitness is the ability of a person's body to carry out an activity that requires maximum physical exertion without experiencing fatigue, even being able to perform other physical activities. ${ }^{16}$ There are various ways to perform a physical fitness test, one of which is multistage fitness (MFT). Other methods include the Indonesian Physical Fitness test (TKJI), walking tests - running for 15 minutes (balke test), running for 12 minutes (cooperating tests), running $2.4 \mathrm{~km}$ (cooperating tests), and going up and down benches (casch). ${ }^{17}$
The more a person inhales oxygen, the more energy is produced. The ability of the maximum lung capacity to accommodate oxygen can be seen from VO2 max. A large VO2 max value indicates better physical fitness. ${ }^{18}$

According to Gok et al., learning methods based on problems in science lessons, including Natural Sciences, are basic. Through this method, students seek to find solutions to problems faced by utilizing the information presented. ${ }^{19}$ With this method, students are expected to not only memorize what is written in the book but also build a critical mindset to decide how to solve the problem and understand the essence of the material being studied. ${ }^{20}$ There are four stages that students must go through in problem-based learning, includes: understanding the problems faced, designing steps to be taken to solve the problem, implementing what has been designed, and evaluating its implementation.

\section{METHOD AND MATERIAL}

The population taken for this study was the fifth-grade elementary school students in Tabanio. The research sample was taken from all grade $\mathrm{V}$ elementary school students in Tabanio Village, Takisung District, Tanah Laut Regency which consisted of SDN Tabanio 1, SDN Tabanio 2, and SDN Tabanio 3 who met the following inclusion criteria: aged 10-13 years, had an index Normal body mass (BMI), not smoking, not menstruating, physically healthy, that is, at the time of the study the probands was not sick and did not have a history of heart and lung disease, cooperative, research subjects can be invited to collaborate to carry out research procedures. VO2 $\max$ is the maximum oxygen consumption in $\mathrm{ml} / \mathrm{kg} /$ minute which can be measured using a multistage fitness test. For the measurement of blood pressure, the instruments used include the mercury sphygmomanometer $\left(\mathrm{ABN}^{\circledR}\right)$ with a small 4 $\mathrm{x}$ cuff $13 \mathrm{~cm}$ and a stethoscope (GEA $®$ )

Subjects follow the second part of the research process using classroom action research methods. They will get a case problem related to the digestive 
system material in science lessons. In this case, the ability to understand problems will be assessed, plan solutions and carry out problem-solving based on the plans prepared. The results will be analyzed using quantitative analysis methods.

\section{RESULTS AND DISCUSSION}

From the results of the research that has been done, it was found that the diastolic blood pressure average before and after the Multistage Fitness Test (MFT) was $74.73 \mathrm{mmHg}$ and $85.54 \mathrm{mmHg}$, respectively. While the results of the study for systolic blood pressure, it was found that the average systolic blood pressure before and after MFT was $111.62 \mathrm{mmHg}$ and $126.22 \mathrm{mmHg}$, respectively (table $1)$.

Based on these results, it can be seen that there is an increase in diastolic and systolic blood pressure after MFT compared to before MFT. Forjaz et al's study showed that when measuring $80 \%$ of the peak VO2 max, there was an increase in systolic and diastolic blood pressure compared to before measurement. This research was conducted on people with normal blood pressure. ${ }^{22}$ Kusmana's research shows that with dynamic and isometric exercises, there will be an increase in both systolic and diastolic blood pressure. With dynamic training cardiac output increases as the heart rate increases, stroke volume increases as well as contractility. Blood flow to the working muscles will increase due to local vasodilation, on the other hand, blood flow to the non-functioning muscles and visceral organs is reduced by sympathetic vasoconstriction. In isometric exercises, the increased blood pressure is associated with response to pressure. This pressure is mediated by reflex causing the cardiac output to increase with or without changes in vascular resistance, the result is that blood pressure increases with the amount of muscle mass that contracts. ${ }^{23}$

The increase in diastolic and systolic blood pressure before and after MFT was statistically tested with the Wilcoxon test. Previous data were tested for normality using the Shapiro-Wilk test. The results of the normality test of the pretest and posttest data were not normally distributed, when transformed, the data were still not normally distributed. So an alternative test from the Wilcoxon test was carried out and it showed a significant difference between diastolic and systolic blood pressure before and after MFT.

The results of the study for maximum oxygen consumption (VO2 max) obtained an average VO2 $\max$ value was $27.41 \mathrm{ml} / \mathrm{kg} /$ minute. The results showed that the normal VO2 max value in children was $45-50 \mathrm{ml} / \mathrm{kg} / \mathrm{minute}$. This means that the VO2 max score of grade V SD students in Tabanio is below the normal value. ${ }^{24}$

Table 1. Systolic and diastolic blood pressure, VO2 max, and problem-solving abilities mean in ProblemBased Learning.

\begin{tabular}{|c|c|c|c|}
\hline No. & Aspect (Average) & Before the MFT & After the MFT \\
\hline 1 & Systolic blood pressure & 111.62 & 126.22 \\
\hline 2 & Diastolic blood pressure & 74.73 & 85.54 \\
\hline 3 & VO2 max & 70.32 & 82.06 \\
\hline 4 & Problem-solving skill & \multicolumn{2}{|c|}{27.41} \\
\hline
\end{tabular}

The results obtained mean that it is not by the estimation that coastal children with high activity will produce a good VO2 max.

The VO2 max value obtained was then correlated with the difference in blood pressure to determine the effect of VO2 max on systolic and diastolic blood pressure. The results of the correlation test between VO2 max and diastolic blood pressure using the Spearman test showed that there was no significant correlation between $\mathrm{VO} 2$ max and 
diastolic blood pressure. The results of the correlation test between VO2 max and systolic blood pressure using the Spearman test showed that there was a significant correlation between VO2 max and systolic blood pressure. These results are by the research hypothesis that there is an effect of $\mathrm{VO} 2$ max on blood pressure but only on systolic blood pressure.

The VO2 max obtained in the study subjects was below the standard with an average value of $27.41 \mathrm{ml} / \mathrm{kg} /$ minute. This affects the resulting blood pressure. However, it turns out that VO2 max that is below this standard only affects systolic blood pressure, not diastolic blood pressure. The results of this study are from the research of Sadhan et al, who found a correlation between VO2 max and systolic blood pressure. VO2 max has a close relationship with heart function including blood pressure. People who have a high VO2 max value will produce stable systolic blood pressure due to cardiovascular adaptation. Such adaptations include increased stroke volume with decreased heart rate, increased muscle capillarization, and better extraction of oxygen from arteries. Conversely, if the VO2 max is low, it will affect the systolic blood pressure value in the form of a significant increase after activity. ${ }^{25}$

According to research by Armstrong, men and women have no difference in $\mathrm{VO} 2$ max values until puberty. The results obtained in this study indicate that the normal VO2 max value in children is $45-50$ $\mathrm{ml} / \mathrm{kg} /$ minute. This means that the VO2 max scores of grade V SD students in Tabanio are below normal values. $^{26}$

According to Engka et al, to increase VO2 max and gain fitness, aerobic exercise should be done with a frequency of 3-5 times/week training with a training duration of 20-30 minutes. The activity of these coastal children is indeed high but they have not yet been able to reach the training dose that can increase VO2 max. $^{27}$

Sadhan et al who found a correlation between VO2 max and systolic blood pressure. VO2 max has a close relation with heart function including blood pressure. People who have a high VO2 max value will produce stable systolic blood pressure due to cardiovascular adaptation. Such adaptations include increased stroke volume with decreased heart rate, increased muscle capillarization, and better extraction of oxygen from arteries. Conversely, if the VO2 max is low, it will affect the systolic blood pressure value in the form of a significant increase after activity. ${ }^{28}$

VO2 max affects physical fitness because it determines the level of students' ability to do activities, including studying. High VO2 max results in better physical fitness and a way to increase it is by doing physical activity, regular and systematic exercise. ${ }^{29}$ In this study, the subjects attended classes with problem-based learning methods with the theme of the case concerning the human digestive tract which is one of the Natural Science (IPA) materials. In this section, the research method is classroom action research. During this phase, the ability to understand problems will be assessed, plan solutions and carry out problem-solving based on the plans prepared. The results of the quantitative analysis showed the students' problem-solving abilities before and after MSF were 70.32 and 82.06, respectively (Table 1). This means there is an increase in ability after participating in multistage fitness activities.

When doing sports activities, the body continuously moves regularly and the nervous system works the muscles through the delivery of stimuli increasingly working for coordination with repetitive and continuous movements, organ function is encouraged to work optimally, characterized by increased physical fitness and the ability to work for a longer duration. ${ }^{13}$ This activity also increases the number of capillaries to meet oxygen and nutritional needs for cells, including in the brain. The higher the oxygen supply to the brain, the better a person's cognitive abilities. ${ }^{30}$ According to Jansen, the things involved in increasing thinking power related to physical fitness are increased circulation of neurons which has an impact on increasing the supply of oxygen and nutrients to the brain, stimulation of the neurotransmitter that triggers BDNF activation which 
allows nerve cells to communicate with each other, triggers neurogenesis in the brain, and increases visual acuity. ${ }^{30}$

Low levels of fitness are associated with obesity and fatigue and therefore hypokinetic. This reduces productivity. ITB (Bandung Technology Institute) enforces sports as a compulsory subject during the Joint Preparation Stage to avoid low student physical fitness which has an impact on academic achievement. ${ }^{13}$

Abernethy's research proves that IQ tests, memory skills, reasoning power, intelligence in mathematics are better in groups of people who have regular sports activities compared to groups who do not have regular activities. ${ }^{31}$

Research by Yulianti et al was conducted on elementary school students. The children's physical fitness was assessed by the bleep test. The results of the analysis showed that children with unfit conditions had a 5.6 times risk of lower achievement scores than those who were fit. ${ }^{32}$

A similar study was conducted by Hidayat et al on 40 junior high school students to determine the relationship between physical fitness and learning achievement. All research subjects took the multistage fitness test, then their learning achievement was seen from the students' examination report card scores. The results showed that physical fitness and achievement are directly proportional and have a significant relation. Increasing physical fitness is followed by improvement in student academic achievement. ${ }^{18}$

Research by Sunadi et al. conducted on 616 students in 1st and 2nd-semester who took the Sports Course with a fitness test using a physical readliness test (PRT) in the form of running $2.4 \mathrm{~km}$ (cooperative test). The results showed a positive correlation between physical fitness and the achievement of the cumulative grade point average (GPA). In the male subject group, the first semester GPA before and after participating in MKOR activities was 3.28 and 3.31 respectively, while the second semester was 3.11 and 3.17. In the female subject group, the first semester
GPA scores before and after participating in MKOR were 3.31 and 3.33, in the second semester 3.05 and 3.11. There has consistently been an increase in the achievement of student and female GPA after regularly participating in sports activities. This is because every sports movement plays a role in the balance of physics, chemical, and emotional that supports the creation of an appropriate learning atmosphere. ${ }^{13}$

Many factors influence students' achievement. Internal factors such as nutritional status, physical condition, motivation, and genetics. Exercise itself is one of the things that affect the physical condition. External factors such as the social and economic conditions of the family, facilities, and teaching methods. Problem-based learning aims to combine cognitive and metacognitive abilities. ${ }^{33}$

The results of the research by Prasetyoningsih which was conducted to determine the results of the application of problem-based learning, the results showed that this method increased teacher and student activity by $12.92 \%$ and $7.78 \%$, respectively. Besides, this study also shows an increase in problem-solving abilities and student responses in teaching-learning activities, respectively $15.63 \%$ and $16.25 \% .^{34,35}$ This shows that in the learning process, students are not only recipients but also expected to actively express their thoughts. and able to apply knowledge to solve problems. So, students will be stimulated to think critically.

\section{CONCLUSION}

Physical activity, especially regular exercise, is a way to increase VO2 max. Repetitive and systematic movements stimulate organ function to work optimally, characterized by increased physical fitness and denser capillary filling to meet the needs of oxygen and nutrients for cells, including brain cells that make the cognitive abilities will be better. Physical fitness is directly proportional to achievement, increasing physical fitness significantly results in improved student academic achievement. 


\section{REFERENCE}

1. American College Of Sports Medicine. Acsm's Guidelines for Exercise Testing and Prescription (6th Ed). Philadelphia: Lippincott Williams And Wilkins, 2000.

2. Huldani. Difference of VO2 max between students who practice football and those who do not practice soccer at Darul Hijrah Islamic Boarding School. CDK 2008; 35 (7): 394-395.

3. Huldani. The Effect of Hemoglobin Levels and Gender on Maximum Oxygen Consumption of Darul Hijrah Islamic Boarding School Students. CDK 2010: 509-511.

4. Doewes M, Kiyatno, Suradi. Respiration System Contribution to VO2 Max. J Respir Indo. 2011; 31 (1): 10-13.

5. Quinn E. VO2 Max Measures Aerobic Fitness And Maximal Oxygen Uptake. Medical Review Board. 2008

6. Syatria A. Effect of Programmed Training on Blood Pressure in Diponegoro University Medical Faculty Students Participating in Basketball Extracurricular Activities. Semarang: Faculty of Medicine, UNDIP. 2006

7. Anse La. The Effect of the Environment on Basic Movement Skills for Coastal Elementary School Children and Elementary School Children in Kendari City. Dive into Ips. 2008; 1 (23): 45-51.

8. Hodges ANH, Sheel AW, Mayo JR, Et Al. Human Lung Density Is Not Altered Following Normoxic And Hypoxic Moderate-Intensity Exercise: Implications For Transient Edema. J Appl Physiol. 2007; 103: 111-118.

9. Tommy Boone. Effect Of Walking And Running On The Cardiorespiratory System, Muscle Injury, And The Antioxidant System After 30 Min At The Walk-Run Transition Speed. Journal Of Exercise Physiology: 2012; 15 (5)

10. Anggriawan N. The Role of Sports Physiology in Upholding Achievements. Journal of Sports Achievement. 2015; 11 (3): 8-18

11. Huldani, Pattelongi I, Massi MN, Idris I, Bukhari A, Widodo ADW, Uinarni H, Carmelita AB, Trisia A, Gunma S, Prayudhistya BKA, Achmad H. SRP.2020; 11 (6): 474-485. DOI: 10.31838 / Srp.2020.6.74
12. Sugiharto. Fisioneurohormonal in Sports Stressors. Journal of Psychological Science. 2012; 2 (2): 5466.

13. Sunadi D, Soemardji A, Apriantono $T$ \& Wirasutisna KR. Level of Fitness and Learning Achievement. Journal of Sociotechnology. 2018; 17 (2), 326-336.

14. Ratey JJ, Hagerman E. Spark: The Revolutionary New Science Of Exercise And The Brain. New York, NY: Hachette Book Group USA. 2008

15. William G. Perspective: Rich Experiences, Physical Activity Healthy Brains. National Scientific Council On The Developing Child. Www.Developingchild.Net

16. Wiarto, Giri. Physiology And Sports. Yogyakarta: Graha Science; 2013

17. Mahardika, I Made Sriundy. Teaching Evaluation. Surabaya: Unesa University Press; 2010

18. Rosyid AA, Hidayat T. Relationship between Physical Fitness and Student Academic Achievement (Studies in Class VIII Students of SMP Sunan Ampel Porong). Journal of Sports and Health Education. 2014; 4 (1): 213-218

19. Gok, T \& Silay, I. The Effects Of Problem Solving Strategies On Students' Achievement, Attitude And Motivation. Latin- American Journal Of Physics Education. 2010; 4 (1): 721.

20. Selçuk GS, Çalışkan S \& Erol M. The Effects Of Problem Solving Instruction On Physics Achievement, Problem Solving Performance And Strategy Use. Latin American Journal Of Physics Education. 2008; 2 (3): 151-166.

21. Daud A, Suharjana A, Karim MA, Abdullah S, Wardhani S, Tarmoko AH, Et Al. Critical Studies in Mathematics Learning in Junior High School.2010

22. Forjaz CIM, Matsudaira Y, Rodrigues FB, et al. Post exercise changes in blood pressure, heart rate and rate pressure product at different exercise intensities in normotensive humans. Brazilian Journal of Medical and Biological Research 1998; 31: 1247-1255.

23. Kusmana D. Hypertension: definition, prevalence, pharmacotherapy and physical exercise. CDK 2009; 36 (3): 161-167.

24. Armstorng N. Aerobic fitness of children and adolescent. Journal de Pediatria 2006; 82: 406. 
25. Guyton and Hall. Medical physiology textbook. Edition 9 translation by Setiawan I. Jakarta: EGC, 2005.

26. Armstorng N. Aerobic Fitness Of Children And Adolescent. Journal De Pediatria 2006; 82: 406.

27. Ansje E JN, Soempeno B, Suwono. The Effect of Increasing Exercise Intensity on Maximum Oxygen Uptake (VO2 Max) Study in Heart Healthy Club Members. Health Science. 2003; 16 (1): 173- 190.

28. Guyton And Hall. Textbook of Medical Physiology. Edition 9 Translation by Setiawan I. Jakarta: EGC; 2005.

29. Edrizal, M., \& Asnaldi, A. Relationship between VO2max and Student Learning Outcomes. Sport Science. 2018; 18 (1), 10-20.The name of this article is:

30. Jensen, E.Brain-Based Learning: The New Paradigm Of Teaching. Corwin Press.2008

31. Abernethy, LJ, Cooke, RW, \& Foulder-Hughes, L. Caudate And Hippocampal Volumes, Intelligence, And Motor Impairment In 7-Year-Old Children Who Were Born Preterm. Pediatric Research. 2004; 55 (5), 884-893. The name of this article is:

32. Yulianti, A., Damayati, RP, \& Rosiana, NM Physical Fitness and Learning Achievement of Elementary School Children. Proceedings.2017

33. Mathews, Aydinli, J. Problem Based Learning And Adult English Language Learners. CAELA: Center For Applied Linguistics. 2007.

34. Prasetyoningsih, Desi Dwi .. Application of Problem Based Learning Model to Improve Students' Problem Solving Ability in Elementary Science Subjects. UNESA Primary School Teacher Education Research Journal. 2013; 1 (3).

35. Aminuddin Prahatama Putra, Huldani, Achmad Syamsu Hidayat. Learning Devices for Biological Diversity: Examining the use of Troubleshooting to Improve Student Learning Outcomes. SRP. 2019; 10(1): 235-246. doi:10.5530/srp.2019.1.40 